\title{
Repellent foraging scent recognition across bee families ${ }^{1}$
}

\author{
Nadine GAWLETA, Yvonne ZIMMERMANN, Thomas EltZ* \\ Department of Neurobiology, Sensory Ecology Group, University of Düsseldorf, Universitätsstr. 1, \\ 40225 Düsseldorf, Germany
}

Received 20 July 2004 - Revised 4 November 2004 - Accepted 17 November 2004

Published online 7 July 2005

\begin{abstract}
Honeybees and bumblebees avoid probing flowers that have been recently depleted by conspecifics, presumably repelled by odours deposited by the previous visitor (foraging scent marks). Here we show that females of the solitary wool-carder bee Anthidium manicatum (Megachilidae) discriminate against previously visited inflorescences (Stachys officinalis), and that discrimination is equally strong regardless of whether the previous visitor is conspecific or belongs to a different bee family (Bombus terrestris, Apidae). Conversely, workers of B. terrestris responded differentially to different previous visitors, with previous visits by $A$. manicatum eliciting the most pronounced repellent effect. This finding may have resulted from the bumblebees' avoidance of impending aggression by territorial A. manicatum males. Our results emphasize that foraging scent mark recognition is not necessarily linked to sociality, but a trait of individuals foraging in an unpredictable flower visitor community.
\end{abstract}

scent marks / footprints / flower discrimination / Bombus / Anthidium

\section{INTRODUCTION}

Plant-bee interactions are frequently characterised by a high degree of generalization, meaning that sympatric species of bees broadly overlap in their choice of food plants (Waser et al., 1996). Although evidence is scant, this implies that the extent of competition for floral resources among members of different species rivals that among conspecifics, and that foraging decisions of individuals should maximize energy gains in response to the behaviour of a range of competing species. This hypothesis has been applied to guilds of bumblebees (Bombus sp.) faced with the decision of whether to land on and probe a particular flower or inflorescence (Stout et al., 1998). Bumblebees were shown to reject flowers that have been recently visited by conspecifics, thus discriminating against flowers with little or no nectar content (Stout et al., 1998; Stout and Goulson, 2001a; Goulson et al., 1998). Doing cross-species tests with four species of Bombus, Stout et al. (1998) found that the likelihood of flower rejection was largely independent of the species affiliation of the previous visitor. Although other possible mechanisms have not been completely ruled out, mounting evidence suggests that flower discrimination is based on detection of residues of volatile chemicals deposited during previous visits (Goulson et al., 2000). Experiments have demonstrated that bumblebees reject flowers that were treated with extracts of Bombus tarsi, containing mixtures of long-chain hydrocarbons. These mixtures were similar (but not identical) among species of Bombus, thus allowing for the recognition of heterospecific scent marks (Goulson et al., 2000). It is not clear whether the deposition of scent marks is an active process, e.g.

\footnotetext{
* Corresponding author: eltz@uni-duesseldorf.de
}

${ }^{1}$ Manuscript editor: Stan Schneider 
Table I. Overview of test combinations.

\begin{tabular}{lccc}
\hline \multirow{2}{*}{ Previous flower visitor } & \multicolumn{3}{c}{ Test flower visitor } \\
\cline { 2 - 4 } & B. terrestris & B. pascuorum & A. manicatum \\
\hline B. terrestris & $\mathbf{X}$ & $\mathbf{X}$ \\
B. pascuorum & $\mathbf{X}$ & & $\mathbf{X}$ \\
A. manicatum & $\mathbf{X}$ & $\mathbf{X}$ & $\mathbf{X}$ \\
unvisited flowers & $\mathbf{X}$ & & $\mathbf{X}$ \\
\hline
\end{tabular}

mediated by imminent tarsal gland secretion, or whether the volatile residues constitute unavoidable 'footprints', left wherever bumblebees walk (Stout et al., 1998).

Using information of scent deposits on flowers is not restricted to bumblebees. Honeybees (Apis mellifera L.) are known to respond to repellent substances secreted by their conspecifics' mandibular glands (Giurfa, 1993; Giurfa and Nunez, 1992). Furthermore, female solitary Anthophora plumipes (Pallas) have been claimed to use non-visual cues for discriminating among flowers, with recognition of conspecific scents being the likely mechanism (Gilbert et al., 2001).

Because the repellent scent compounds found in bumblebees (long-chain alkanes and alkenes) are common to cuticles of most insects, it is possible that similar marks are deposited by a broad range of flower visitors (Goulson, 2003). It is an open question whether recognition of scent deposits occurs between different genera or families of bees, and whether different species of previous visitors elicit differential repellent effects (see, e.g., conflicting evidence for Apis/Bombus in Williams (1998) and Stout and Goulson (2001b)). In the present study we investigated whether acceptance of flowers by female solitary wool-carder bees, Anthidium manicatum (L.), is influenced by previous visits of worker bumblebees, Bombus terrestris (L.) and viceversa, and whether bumblebees discriminate between different species of previous visitors.

\section{MATERIALS AND METHODS}

The observations were carried out within a $15 \mathrm{~m}^{2}$ stand of Stachys officinalis (L.) in the Botanical Gardens of the Heinrich-Heine-Universität in Düsseldorf. Observations were made from $0800 \mathrm{~h}$ to $1600 \mathrm{~h}$ (local time) from July 14 to 28 in 2003. Throughout this period the weather was hot and dry. Stachis officinalis (Lamiaceae) has vertical inflorescences with one to 30 open heart-shaped flowers providing nectar at the base of a short corolla tube. During the time of the study S. officinalis was highly attractive to several species of bees, with workers of Bombus terrestris and B. pascuorum, and female Anthidium manicatum being the most abundant visitors (in the given order), which were therefore selected as focal species.

For measuring the rates of rejection of 'unvisited' (control) inflorescences by individual foragers, whole inflorescences were covered with mesh bags for at least 3 hours (mostly overnight) before behavioral tests were conducted, so that nectar could accumulate and possible scent-marks evaporate. For an individual acceptance/rejection test, an inflorescence was cut with a short stem and exposed in the foraging path of an individual bee using forceps. It was recorded as 'rejected' if the bee would approach the inflorescence but not land on it or land on it briefly but not probe any flower for nectar. Respectively, inflorescences were regarded as 'accepted' if the forager would land on it and probe at least one flower for nectar (see Stout et al., 1998). An analogous procedure was used to measure rates of rejection for inflorescences that had been visited shortly before the test situation. For this, we cut inflorescences immediately after they had been visited by a bee and presented them to foraging bees within the next 5 minutes. In order to contrast the effects of conspecific versus heterospecific visits on rejection probability, we conducted independent test series using different combinations of the previous visitor species and the test species. Complete reciprocal test series were conducted for females of A. manicatum and workers of $B$. terrestris. Bombus pascuorum workers were used as additional previous visitors in tests on B. terrestris (see Tab. I for an overview of test combinations).

In an attempt to quantify the degree of nectar depletion in inflorescences resulting from visits by a given bee species we assessed the percentage of flowers probed per inflorescence. For quantitative comparison between bee species we distinguished 


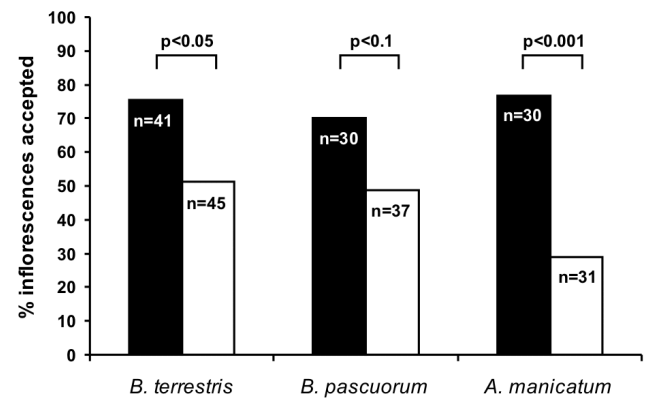

Figure 1. Percentage of inflorescences accepted by foragers of $B$. terrestris, B. pascuorum and $A$. manicatum, depending on whether they were previously unvisited (controls, black bars) or visited by conspecifics (white bars).

two categories, with (a) less than $50 \%$ of the flowers/ inflorescence probed, or (b) more than $50 \%$ of the flowers/inflorescence probed.

\section{RESULTS}

\subsection{Rejection of inflorescences pre- viously visited by conspecifics}

First, we compared the rejection rates of unvisited versus visited inflorescences within each of the three species separately. Inflorescences previously visited by conspecifics were rejected significantly more often than unvisited ones in $B$. terrestris $\left(\mathrm{N}=86 ; \mathrm{df}=1 ; \chi^{2}=5.51\right.$; $P<0.05)$ and $A$. manicatum $(\mathrm{N}=61 ; \mathrm{df}=1$; $\left.\chi^{2}=13.87 ; P<0.001\right)$. In $B$. pascuorum there was a tendency in the same direction, but it was not significant $\left(\mathrm{N}=67\right.$; df $=1 ; \chi^{2}=3.10$; $P<0.1$ ). Of the three species, A. manicatum showed the highest absolute rate of rejection of visited inflorescences (70.9\%; see Fig. 1). However, when compared statistically, there was no significant difference between species concerning the likelihood of rejecting inflorescences previously visited by conspecifics $\left(\mathrm{N}=113 ; \mathrm{df}=2 ; \chi^{2}=4.06 ;\right.$ n.s. $)$.

\subsection{Rejection of inflorescences previously visited by heterospecific foragers}

We analyzed whether individuals of $B$. terrestris and $A$. manicatum also reject inflores-
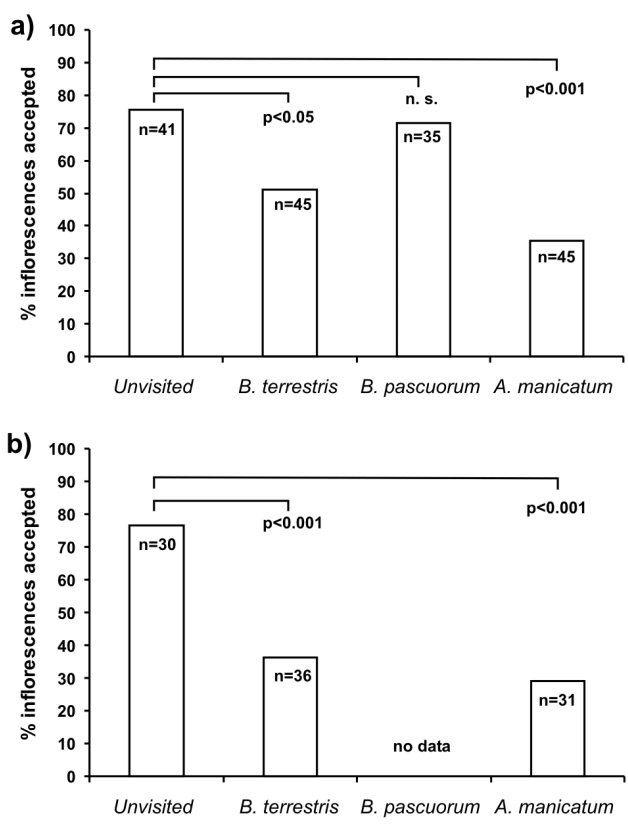

Figure 2. Percentage of inflorescences accepted by foragers of B. terrestris (a) and A. manicatum (b) depending on the previous flower visitor.

cences in response to visits by foragers of a different species, and if so, whether the rate of rejection differs depending on the species of the previous visitor.

In comparison to unvisited controls foraging $B$. terrestris were significantly more likely to reject inflorescences previously visited by $A$. manicatum $\left(\mathrm{N}=86 ;\right.$ df $=1 ; \chi^{2}=13.877$; $P<0.001$ ), but there was no difference for those previously visited by $B$. pascuorum $\left(\mathrm{N}=76 ; \mathrm{df}=1 ; \chi^{2}=0.171 ;\right.$ n.s. $)$. When we compared the rejection rates of $B$. terrestris after previous visits by conspecifics, previous visits by $B$. pascuorum and previous visits by A. manicatum, there was a significant difference $\left(\mathrm{N}=125 ; \mathrm{df}=2 ; \chi^{2}=10.14 ; P<0.01\right)$, with previous visits by $A$. manicatum eliciting the strongest repellent effect (see Fig. 2).

In comparison to unvisited controls foraging A. manicatum were significantly more likely to reject inflorescences previously visited by $B$. terrestris $\left(\mathrm{N}=66 ; \mathrm{df}=1 ; \chi^{2}=10.867 ; P<\right.$ $0.001)$. No data were available to compare the effect of previous visits by B. pascuorum. There was no significant difference when we 


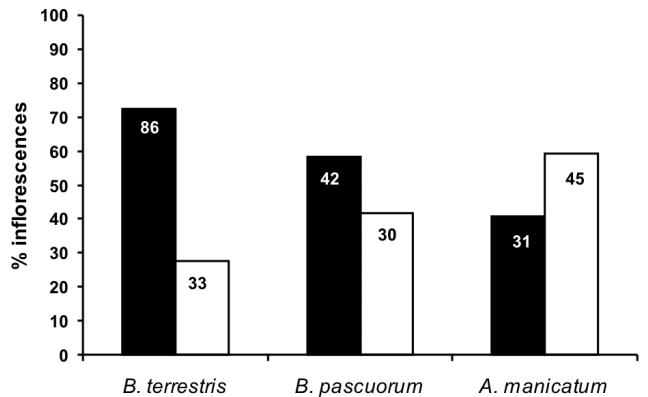

Figure 3. Percentage of inflorescences with more than $50 \%$ of flowers probed (black bars) and of inflorescences with fewer than $50 \%$ of flowers probed (white bars), for $B$. terrestris, B. pascuorum and A. manicatum respectively.

compared the rejection rate of $A$. manicatum after previous visits by conspecifics with that after previous visits by $B$. terrestris, $(\mathrm{N}=67$; $\mathrm{df}=1 ; \chi^{2}=0.54 ;$ n.s. $)$.

\subsection{Foraging behaviour}

The three species varied significantly in the percentage of flowers probed per visited inflorescence $\left(\mathrm{N}=267 ; \mathrm{df}=2 ; \chi^{2}=19.14 ; P<\right.$ 0.0001 ), with $B$. terrestris visiting the largest proportion of flowers, followed by $B$. pascuorum and A. manicatum (Fig. 3). The low percentage of flowers probed by foraging $A$. manicatum corresponded to our impression that they were prone to rapid switches between inflorescences and moved quickly through the patch.

\section{DISCUSSION}

Our data demonstrate that A. manicatum rejects flowers that have recently been visited by conspecifics. As in bumblebees, it is likely that this behaviour is mediated by volatile chemicals deposited by the previous visitor. This is the first report of such a repellent effect for a megachilid bee and strengthens the view that use of scent marks is not confined to social Apidae. The only other solitary bee that reportedly uses scent marks when foraging is the anthophorid Anthophora plumipes (Gilbert et al., 2001). Traditionally, scent marking has been regarded as a typical trait of social bees that enhances colony foraging efficiency, emphasizing attractive effects that guide nest mates to rewarding flowers and minimizes the time colonies have to invest in searching for food (Cameron, 1981; Schmitt et al., 1991). However, on an individual basis both attractive and repellent scent marks may also be beneficial, e.g. by reducing the risk of immediate revisits of depleted flowers by a given individual or by facilitating rapid revisits of rewarding flowers that cannot be completely depleted during one single visit. Our finding that the solitary A. manicatum uses scent-marks clearly emphasizes these individual benefits and suggests that repellent scent marks are not necessarily a way of social communication in the social Apinae. Generally, it is still not clear if the repellent scents are actively deposited or simply unavoidable footprints left by foragers, which is an important aspect when considering their function.

Solitary A. manicatum as well as social $B$. terrestris clearly rejected flowers that were previously visited by the other species respectively, suggesting that recognition of scent marks takes place across members of different bee families. In $B$. terrestris there was also a significant difference of the strength of the repellent effects elicited by different species of previous visitors, suggesting that $B$. terrestris can (and does) discriminate between scent marks of different bee species. But why should foraging decisions depend on the species affiliation of the previous visitor? Discrimination would clearly be beneficial if the extent of resource depletion differs between species, an assumption that may seem validated by the evident differences in the percentage of probed flowers per inflorescence. However, the thoroughness of foraging by the different species does not correspond to the observed repellent effects. Especially the strong repellent effect of previous visits by $A$. manicatum is unlikely related to lack of nectar in the visited flowers, since $A$. manicatum individuals are the least thorough in their foraging. This finding also emphasizes that the decision making process is not based on the direct perception of nectar levels present in the flowers.

We hypothesize that the strong repellent effect of previous visits by A. manicatum is related to the territorial behaviour of the species. Male A. manicatum establish and defend small resource-based mating territories around 
their females' food plants. The males constantly patrol these territories and chase away other flower visitors, including bumblebees, by physically attacking them with abdominal spines. The harassed individuals often carry away severe wounds or even die after the attacks (Pechuman, 1967; Wirtz et al., 1988; Wirtz et al., 1992). The strongly decreased acceptance rate of flowers previously visited by $A$. manicatum in $B$. terrestris could be a result of this aggressive behaviour. Bumblebees may associate perceived Anthidium scent with previously experienced attacks and avoid marked inflorescences.

\section{ACKNOWLEDGEMENTS}

We thank P. Thielen, A. Fischbach, and the entire staff of the Botanical Gardens for patience, plants and advice. D. Goulson, K. Lunau, and the members of the Sensory Ecology Group seminar helped to improve the manuscript.

Résumé - Reconnaissance du marquage odorant répulsif suite au butinage parmi les familles d'abeilles. La recherche de nourriture occasionne pour les insectes butineurs des coûts sous forme de temps passé par visite de fleurs et d'énergie nécessaire pour exploiter les ressources. Afin de minimiser ces coûts, les butineurs doivent pouvoir différencier, avant même de les tester, les fleurs qui vont leur donner une récompense de celles qui ne vont rien fournir. De fait, il a été montré que les ouvrières de bourdons (Bombus sp.) discriminent les fleurs vides, i.e. celles déjà visitées par d'autres bourdons peu de temps auparavant. Des études antérieures ont suggéré que cette discrimination ne reposait pas sur une perception directe du nectar, mais que des marques odorantes laissées par le visiteur précédent étaient perçues et soumises à une évaluation indirecte de la teneur en nectar attendue. Cette capacité n'est pas limitée à l'espèce, car des marques odorantes peuvent être perçues réciproquement par d'autres espèces au sein du genre Bombus (Stout et al., 1998; Stout et Goulson, 2001a ; Goulson et al., 1998). Dans cette étude nous montrons que l'enregistrement et l'utilisation des marques odorantes existent aussi chez les abeilles solitaires et que la perception réciproque a lieu aussi entre membres de différentes familles d'abeilles. Des femelles de l'abeille solitaire «tapissière » ou « cotonnière », Anthidium manicatum (L.) (Megachilidae), qui butine principalement la Bétoine officinale (Stachys officinalis) discriminaient dans la même mesure les fleurs qui avaient été visitées peu auparavant par des individus de la même espèce et celles qui avaient été visitées par des bourdons terrestres (Bombus terrestris, Apidae). Chez les bourdons ter- restres par contre, la probabilité de rejet dépendait de l'espèce du visiteur précédent. Les fleurs étaient d'autant plus évitées qu'elles avaient été visitées auparavant par des anthidies. Cet effet ne repose vraisemblablement pas sur une teneur en nectar particulièrement faible des fleurs visitées par les anthidies, mais reflète la tendance des bourdons de se soustraire à l'agression territoriale des mâles d'Anthidium (en évitant l'odeur des anthidies). Visiblement l'appréciation des fleurs d'après les odeurs laissées par les visiteurs précédents ne se limite pas aux abeilles eusociales. Nos résultats renforcent l'interprétation selon laquelle le comportement sert au niveau individuel à optimiser la recherche de nourriture, et le cas échéant aussi à éviter les visites répétées d'une fleur par le même individu.

Bombus / Anthidium / discrimination / butinage / marquage odorant / marquage par les tarses

Zusammenfassung - Erkennung der abweisenden Duftmarkierung nach Sammelaktivität von unterschiedlichen Bienenfamilien. Bei der Nahrungssuche entstehen Blütenbesuchern Kosten in Form der pro Blütenbesuch aufzuwendenden Zeit und der zur Ausbeutung der Ressourcen notwendigen Energie. Um diese Kosten zu minimieren, sollten Blütenbesucher deshalb bereits vor der Beprobung in der Lage sein, zwischen belohnenden und unbelohnenden Blüten zu unterscheiden. Tatsächlich diskriminieren Hummelarbeiterinnen (Bombus) nachweislich gegen vor kurzer Zeit von anderen Hummelindividuen besuchte, d.h. geleerte Blüten bzw. Blütenstände. Durch frühere Studien wurde nahegelegt, dass diese Diskriminierung nicht auf einer direkten Perzeption von Nektar beruht, sondern dass Duftmarken der vorherigen Besucher wahrgenommen und zur indirekten Bewertung des zu erwartenden Nektargehalts herangezogen werden. Diese Fähigkeit ist nicht auf die Artgrenzen beschränkt, denn die Duftmarken können innerhalb der Gattung Bombus von Angehörigen unterschiedlicher Spezies wechselseitig wahrgenommen werden (Stout et al., 1998; Stout und Goulson, 2001a; Goulson et al., 1998). In der vorliegenden Untersuchung zeigen wir, dass die Registrierung und Verwertung der Duftmarken auch bei solitären Bienenarten vorkommt und dass wechselseitige Wahrnehmung auch zwischen Angehörigen verschiedener Bienenfamilien stattfindet. Weibchen der solitären Wollbiene (Anthidium manicatum (L.), Megachilidae), die am Gewöhnlichen Ziest (Stachys officinalis) fouragierten, diskriminierten in gleichem Maße gegen Blütenstände, die vor kurzem von Artgenossen besucht worden waren, als gegen solche, die vorher von Erdhummeln (Bombus terrestris, Apidae) besucht worden waren. Bei Erdhummeln dagegen war die Ablehnungswahrscheinlichkeit von der Artzugehörigkeit des Vorbesuchers abhängig. Am stärksten wurden Blütenstände abgelehnt, die vorher von 
Wollbienen besucht worden waren. Wahrscheinlich gründete dieser Effekt nicht auf einem besonders niedrigen Nektargehalt von Wollbienen besuchten Blütenständen, sondern reflektiert die Tendenz von Hummeln, sich der Aggression territorialer Wollbienenmännchen zu entziehen (durch Vermeidung von Wollbienengeruch).

Offensichtlich ist die Bewertung von Blüten anhand der von Vorbesuchern hinterlassen Gerüche nicht auf hoch-soziale Bienen beschränkt. Unsere Ergebnisse bekräftigen die Interpretation, dass das Verhalten auf individueller Ebene zur Optimierung der Nahrungssuche dient, u. U. auch zur Vermeidung von wiederholten Besuchen einer Blüte durch dasselbe Individuum.

Bombus / Anthidium / Duftmarke / Fußabdruck / Blütendiskrimierung

\section{REFERENCES}

Cameron S.A. (1981) Chemical signal in bumble bee foraging, Behav. Ecol. Sociobiol. 9, 257260.

Gilbert F., Azmeh S., Barnard C., Behnke J., Collins S.A., Hurst J., Shuker D. (2001) Individually recognizable scent marks on flowers made by a solitary bee, Anim. Behav. 61, 217-229.

Giurfa M. (1993) The repellent scent mark of the honeybee Apis melifera ligustica and its role as a communication cue during foraging, Insectes Soc. 40, 59-67.

Giurfa M., Nuñez J.A. (1992) Honeybees mark with scent and reject recently visited flowers, Oecologia $89,113-117$.

Goulson D. (2003) Bumblebees - behavior and ecology, Oxford University Press, Oxford, 235 p.

Goulson D., Hawson S.A., Stout J.C. (1998) Foraging bumblebees avoid flowers already visited by conspecifics or by other bumblebee species, Anim. Behav. 55, 199-206.

Goulson D., Stout J.C., Langley J., Hughes W.O.H. (2000) Identity and function of scent marks deposited by foraging bumblebees, J. Chem. Ecol. 26, 2897-2911.

Pechuman L.L. (1967) Observations on behavior of bee Anthidium manicatum (L.), J. N. Y. Entomol. Soc. 75, 68-73.

Schmitt U., Lübke G., Francke W. (1991) Tarsal secretion marks food sources in bumblebees (Hymenoptera: Apidae), Chemoecology 2, 3540.

Stout J.C., Goulson D. (2001a) The influence of nectar secretion rates on the responses of bumblebees (Bombus spp.) to previously visited flowers, Behav. Ecol. Sociobiol. 52, 239-246.

Stout J.C., Goulson D. (2001b) The use of conspecific and interspecific scent marks by foraging bumblebees and honeybees, Anim. Behav. 62, $183-189$.

Stout J.C., Goulson D., Allen J.A. (1998) Repellent scent-marking of flowers by a guild of foraging bumblebees (Bombus spp.), Behav. Ecol. Sociobiol. 43, 317-326.

Waser N.M., Chittka L., Price M., Williams N.-M., Ollerton J. (1996) Generalization in pollination systems, and why it matters, Ecology 77, 10431060.

Williams C.S. (1998) The identity of the previous visitor influences flower rejection by nectarcollecting bees, Anim. Behav. 56, 673-681.

Wirtz P., Kopka S., Schmoll G. (1992) Phenology of two territorial solitary bees, Anthidium manicatum and A. florentinum (Hymenoptera, Megachilidae), J. Zool. 228, 641-651.

Wirtz P., Szabados M., Pethig H., Plant J. (1988) An extreme case of interspecific territoriality - male Anthidium manicatum (Hymenoptera, Megachilidae) wound and kill Intruders, Ethology 78, 159167. 